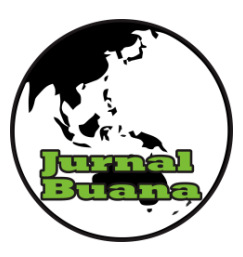

\title{
ANALISIS PERUBAHAN KERAPATAN VEGETASI KOTA PADANG MENGGUNAKAN CITRA LANDSAT TAHUN 2005 DAN 2015
}

\author{
Kurnia Sari $^{1}$ Ernawati $^{2}$ Febriandi $^{2}$ \\ Program Studi Geografi \\ Jurusan Geografi \\ Fakultas Ilmu Sosial Universitas Negeri Padang \\ Email: kurniasari704@gmail.com
}

\begin{abstract}
ABSTRAK
Tujuan penelitian ini untuk mengetahui kerapatan vegetasi, perubahan luas lahan bervegetasi, tingkat ketelitian citra landsat kota Padang tahun 2005 dan 2015. Dari hasil penelitian menunjukan bahwa: (1)Kerapatan vegetasi di Kota Padang memiliki lima kelas klasifikasi kerapatan yaitu kelas kerapatan sangat rapat, rapat, cukup rapat, jarang, dan tidak bervegetasi. Berdasarkan luas lahan kerapatan vegetasi Kota Padang pada tahun 2005 kerapatan vegetasi sangat rapat memiliki luas 44.265,59 ha $(62,10 \%)$, kerapatan rapat $3.382,80$ ha $(4,75 \%)$, kerapatan cukup rapat 5.930,43 ha $(8,32 \%)$, kerapatan vegetasi jarang $5.124,32$ ha $(7,19 \%)$, dan kerapatan tidak bervegetasi $12.578,91$ ha $(17,65 \%)$. Pada tahun 2015 kerapatan sangat rapat memiliki luas 4.411,62 ha (6,19\%), kerapatan rapat 13.960,69 ha (19,59\%), kerapatan cukup rapat 27.066,92 ha (37,97\%), kerapatan jarang $11.424,15$ ha $(16,03 \%)$, dan kerapatan tidak bervegetasi $14.418,69$ ha (20,23\%). (2)Perubahan luas lahan vegetasi terbesar, terjadi pada kelas kerapatan vegetasi sangat rapat dari 44.265,59 Ha tahun 2005 berkurang menjadi 4.411,62 Ha pada tahun 2015. (3)Tingkat ketelitian citra Landsat dari hasil uji akurasi NDVI dengan teknik pengolahan Confussion Matrix, diperoleh akurasi 85,45\%, telah terjadi pengurangan informasi yang disebabkan adanya tutupan awan dan kerusakan citra pada tahun 2015.
\end{abstract}

Kata Kunci: kerapatan vegetasi, Landsat, NDVI, Padang.

\begin{abstract}
The purpose of this study was to determine vegetation density, changes in vegetation land area, accuracy level of Landsat city Padang images in 2005 and 2015. The results showed that: (1) Vegetation density in Padang City has five classes of density classification namely density class very tight, tight quite tight, rare, and not vegetated. Based on the vegetation density area of Padang City in 2005, very tight vegetation density has an area of 44,265.59 ha (62.10\%), density of 3,382.80 ha (4.75\%), density is quite tight, 5,930.43 ha (8,32\%), rare vegetation density 5,124.32 ha (7.19\%), and non-vegetated density 12,578.91 ha (17.65\%). In 2015 the very tight density had an area of 4,411.62 ha (6.19\%), meeting density 13,960.69 ha (19.59\%), quite tight density 27,066.92 ha (37.97\%), rare density 11,424 15 ha (16.03\%), and non-vegetated density 14,418.69 ha (20.23\%). (2) Changes in the largest vegetation area, occur in very tight vegetation density classes from 44,265.59 Ha in 2005 reduced to 4,411.62 Ha in 2015. (3) The level of accuracy of Landsat images from NDVI accuracy test results with Confussion Matrix processing techniques, obtained an accuracy of $85.45 \%$, there has been a reduction in information due to cloud cover and image damage in 2015.
\end{abstract}

Keyword: vegetation density, Landsat, Normalized Difference Vegetation Index (NDVI), Padang

\footnotetext{
${ }^{1}$ Mahasiswa Program Studi Geografi

${ }^{2}$ Dosen Jurusan Geografi Fakultas Ilmu Sosial Universitas Negeri Padang
} 
PENDAHULUAN

Kota Padang merupakan Ibukota Propinsi Sumatera Barat. Aktivitas dan pelayanan penduduk yang mengakibatkan Kota Padang mengalami perkembangan yang cukup cepat. Disadari atau tidak, bahwa laju pertumbuhan penduduk tidak akan pernah berhenti, bahkan senantiasa menunjukkan peningkatan pertumbuhan penduduk.

Berdasarkan data Badan Pusat Statistik Propinsi Sumatera Barat tahun 2016 menjelaskan bahwa penduduk Sumatera Barat dari tahun ke tahun jumlahnya terus meningkat untuk lebih jelasnya dapat dilihat pada tabel 1 .

Tabel 1. Pertumbuhan Jumlah Penduduk Kota Padang

\begin{tabular}{clrrrr}
\hline \multirow{2}{*}{ No } & \multirow{2}{*}{ Kecamatan } & \multicolumn{3}{c}{ Pertumbuhan Jumlah Penduduk (ribu) } \\
\cline { 3 - 6 } & & $\mathbf{2 0 0 5}$ & $\mathbf{2 0 0 9}$ & $\mathbf{2 0 1 4}$ & $\mathbf{2 0 1 5}$ \\
\hline 1 & Bungus Teluk Kabung & 23.197 & 24.417 & 24.137 & 24.408 \\
2 & Lubuk Kilangan & 40.538 & 44.552 & 52.757 & 53.651 \\
3 & Lubuk Begalung & 97.560 & 109.793 & 115.286 & 117.321 \\
4 & Padang Selatan & 60.022 & 64.458 & 59.038 & 59.287 \\
5 & Padang Timur & 83.151 & 88.510 & 78.975 & 79.151 \\
6 & Padang Barat & 59.657 & 62.010 & 45.846 & 45.907 \\
7 & Padang Utara & 72.766 & 77.509 & 70.252 & 70.444 \\
8 & Nanggalo & 55.669 & 59.851 & 59.654 & 60.157 \\
9 & Kuranji & 110.316 & 123.771 & 138.584 & 141.342 \\
10 & Pauh & 50.204 & 54.846 & 66.661 & 68.448 \\
11 & Koto Tangah & 148.264 & 166.033 & 178.456 & 182.296 \\
\hline \multicolumn{2}{c}{ Jumlah } & $\mathbf{8 0 1 . 3 4 4}$ & $\mathbf{8 7 5 . 7 5 0}$ & $\mathbf{8 8 9 . 6 4 6}$ & $\mathbf{9 0 2 . 4 1 3}$ \\
\hline
\end{tabular}

Sumber: Padang Dalam Angka 2016

Bertambahnya jumlah penduduk dan pembangunan yang pesat di Kota Padang akan berpengaruh cukup besar terhadap perubahan penggunaan lahan. Pertumbuhan penduduk yang tinggi akan mendorong perubahan penggunaan lahan, semakin besar pertumbuhan penduduk maka semakin banyak tuntutannya terhadap lahan.

Berdasarkan data Badan Pusat

menyatakan bahwa dari tahun 2014 ke 2015 terjadi perubahan penggunaan lahan. Penggunaan lahan yang mengalami penambahan luas yaitu perumahan. Sebaliknya terdapat pula penyempitan lahan terhadap tanah jasa, sawah non irigasi, ladang, kebun campuran, dan tanah kosong. Untuk lebih jelasnya perubahan penggunaan lahan di Kota Padang dapat dilihat pada Tabel 2.

Statistik Kota Padang tahun 2016

Tabel 2. Luas Lahan Kota Padang

\begin{tabular}{clrr}
\hline \multirow{2}{*}{ No } & & \multicolumn{2}{c}{ Luas Lahan (ha) } \\
\cline { 3 - 4 } & & $\mathbf{2 0 1 4}$ & $\mathbf{2 0 1 5}$ \\
\hline 1 & Perumahaan & $6.972,35$ & $6.989,41$ \\
2 & Industri & 702,25 & 702,25 \\
3 & Tanah Jasa & 715,25 & 715,25 \\
4 & Sawah Beririgasi Teknis & $4.934,00$ & $4.934,00$ \\
5 & Sawah Non Beririgasi & 48,19 & 44,92 \\
6 & Ladang/Tegalan & 940,27 & 939,15 \\
7 & Kebun Campuran & $13.700,42$ & $13.697,00$ \\
8 & Tanah Kosong & 7,19 & 3,89 \\
9 & Semak & $1.296,19$ & $1.496,24$ \\
10 & Rawa & 120,00 & 120,00 \\
11 & Hutan Lebat & $35.448,00$ & $35.448,00$ \\
12 & Sungai & 379,45 & 379,45 \\
\hline & & $\mathbf{6 5 . 2 6 3 , 5 6}$ & $\mathbf{6 5 . 4 6 9 , 5 6}$ \\
\hline
\end{tabular}

Sumber: Padang Dalam Angka 2016 
Penggunaan lahan dengan kerapatan vegetasi yang bermacam-macam banyak dijumpai di Kota Padang. Dalam penelitian Anargi (2008), klasifikasi penggunaan lahan didasarkan pada penyederhanaan dari klasifikasi USGS tingkat I yang dapat dibedakan dalam penggunaan lahan terbangun antara lain pemukiman, industri, pasar, lapangan olahraga dan penggunaan lahan tidak terbangun yang terdiri dari hutan, kebun, sawah, tegalan. Dari klasifikasi tersebut akan memudahkan dalam mengetahui penggunaan lahan yang mempunyai kerapatan vegetasi sangat rapat hingga penggunaan lahan tidak bervegetasi di Kota Padang.

Penggunaan lahan dengan kerapatan vegetasi sangat rapat di Kota Padang masih banyak dijumpai di Kecamatan Koto Tangah, Kecamatan Kuranji, Kecamatan Bungus dan Kecamatan Pauh. Di Kecamatan tersebut masih banyak penggunaan lahan berupa hutan, perkebunan, dan semak belukar. Untuk penggunaan lahan dengan kerapatan vegetasi yang sedikit tersebar merata di Kota Padang seperti di Kecamatan Padang Utara, Padang Barat, Padang Timur dan Padang Selatan. Dengan penggunaan lahan berupa pemukiman, industri, perusahaan, pasar, pelabuhan, dan lain sebagainya.

Semakin tinggi kerapatan vegetasi pada suatu lahan, maka akan semakin rendah suhu permukaan di sekitar lahan tersebut, begitu juga sebaliknya. Suhu permukaan yang tinggi ini banyak ditemui di daerah perkotaan, karena penggunaan lahannya seringkali mempunyai kerapatan vegetasi yang rendah. Tinggi rendahnya suatu kerapatan vegetasi dapat diketahui dengan menggunakan teknik NDVI (Normalized Difference Vegetation Index), yang merupakan sebuah transformasi citra penajaman spektral untuk menganalisa halhal yang berkaitan dengan vegetasi (Putra, 2011 dalam Rahmi, 2009).
Penginderaan jauh merupakan teknik yang dipandang sangat penting untuk dikuasai oleh para pengelola sumber daya alam. Ilmu-ilmu terapan seperti pertanian, perkebunan, kehutanan, tata kota, dan lainlain akan lebih mudah jika dalam pengelolaannya menggunakan data penginderaan jauh. Bahkan menjadi tidak efisien jika melakukan inventarisasi, survey penggunaan lahan, survey bangunan menggunakan cara pengukuran langsung di lapangan secara keseluruhan. Namun bukan hal yang bijaksana pula jika hanya mengandalkan data penginderaan jauh tanpa melakukan cek lapangan. Pemantauan perkembangan suatu kerapatan vegetasi disuatu daerah merupakan salah satu pemanfaatan dari teknik penginderaan jauh.

Melihat permasalahan di atas, perlu dilakukan suatu pemantauan kerapatan vegetasi di Kota Padang secara cepat dengan memanfaatkan teknologi penginderaan jauh dengan menggunakan citra landsat 8 agar mendapatkan hasil yang maksimal. Hasil analisis perubahan kerapatan vegetasi ini diharapkan dapat dipergunakan sebagai data pendukung untuk pengendalian alih fungsi lahan dalam rangka mempertahankan tata ruang yang tetap memberikan kenyamanan.

Vegetasi adalah tumbuh-tumbuhan yang menutupi permukaan bumi pada daerah tertentu yang dapat berupa pohon, herba, rumput maupun tumbuhan tingkat rendah. Dengan dinamika populasi didalamnya sehingga dalam kurun waktu tertentu dapat mengalami perubahan komposisi jenis tumbuhan penyusun. Dengan demikian, dinamika yang terjadi di dalam spesies penyusun komunitas yang hidup bersama-sama dan saling berinteraksi (Oosting, 1956 dalam Rahmi, 2009).

Penginderaan jauh (remote sensing) sering disingkat inderaja, adalah ilmu dan seni untuk memperoleh informasi tentang suatu obyek, daerah, atau fenomena melalui 
analisis data yang diperoleh dengan suatu alat tanpa kontak langsung dengan obyek, daerah, atau fenomena yang dikaji (Lillesand dan Kiefer, 1990 dalam Anargi, 2008).

Sistem Penginderaan Jauh ialah serangkaian komponen yang digunakan untuk penginderaan jauh. Rangkaian komponen itu berupa tenaga, objek, sensor, data dan pengguna data. Karena tidak semua tenaga yang berasal dari matahari dapat mencapai bumi, interaksi antara tenaga dan atmosfer sering dimasukkan ke dalam sistem penginderaan jauh. Demikian pula halnya dengan interaksi antara tenaga dan objek, karena hasil interaksinya menentukan besarnya tenaga yang dapat mencapai sensor (Sutanto,1986 dalam Anargi, 2008).

Interpretasi citra merupakan perbuatan mengkaji foto udara atau citra dengan maksud untuk mengidentifikasi objek dan menilai arti pentingnya objek tersebut (Este dan Simonett, 1975 dalam Rahmi 2009). Interpretasi citra, penafsir mengkaji citra dan berupaya mengenali objek melalui tahapan kegiatan, yaitu: deteksi, identifikasi, dan analisis.

Ketersediaan data satelit, khususnya data landsat MSS, telah membuat aplikasi memungkinkan, karena memperoleh keuntungan liputan area yang luas, kemampuan pemrosesan data komputer dan kemampuan liputan berturutan dari data (C.P. Lo.terjemahan Bambang, 1995 dalam Virma, 2013).

Interpretasi citra penginderaan jauh dapat dilakukan dengan dua cara, yaitu: (1) Interpretasi citra secara manual data penginderaan jauh merupakan pengenalan karakteristik obyek secara keruangan (spasial) mendasarkan pada unsur-unsur interpretasi citra penginderaan jauh. Interpretasi manual dilakukan terhadap citra fotografi dan non-fotografi yang sudah dikonversi ke dalam bentuk foto atau citra.
Interpretasi manual pada citra penginderaan jauh yang sudah terkoreksi, baik terkoreksi secara radiometrik maupun secara geometrik. Sehingga pengguna tinggal melakukan identifikasi obyek yang tergambar pada citra atau foto. (2) Interpretasi citra secara digital dilakukan dengan bantuan komputer. Di dalam interpretasi citra penginderaan jauh digital, pengguna dapat melakukanya mulai dari pengolahan/pra-pengolahan (koreksikoreksi citra) penajaman citra, hingga klasifikasi citra. Namun dapat juga menggunakan data/ citra penginderaan jauh digital yang sudah terkoreksi, sehingga pengguna tinggal melakukan klasifikasi dan tidak perlu melakukan pra-pengolahan data.

Kerapatan vegetasi adalah satu aspek yang mempengaruhi karakteristik vegetasi dalam citra. Kerapatan vegetasi umumnya diwujudkan dalam bentuk persentase untuk mengetahui tingkat suatu kerapatan vegetasi. Siti Imami (1998 dalam Virma, 2013) telah mengadakan penelitian untuk mengetahui sejauh mana hubungan kerapatan vegetasi terhadap pantulan spektralnya dengan analisis digital. Pada data Landsat ditemukan korelasi positif sebesar >0,9 antar indeks vegetasi dengan kerapatan vegetasi hutan daerah penelitian.

\section{METODE PENELITIAN}

Penelitian ini menggunakan jenis penelitian deskriptif. Penelitian ini dilakukan selama 5 bulan (Agustus 2018 Januari 2019), di Kota Padang Propinsi Sumatera Barat, terletak antara $00^{\circ} 44^{\prime} 00^{\prime \prime}$ $-01^{\circ} 08^{\prime} 35^{\prime \prime}$ LS dan $100^{\circ} 05^{\prime} 05^{\prime \prime}-100^{\circ}$ 34' 09" BT. Lebih jelasnya dapat dilihat pada gambar 1. 


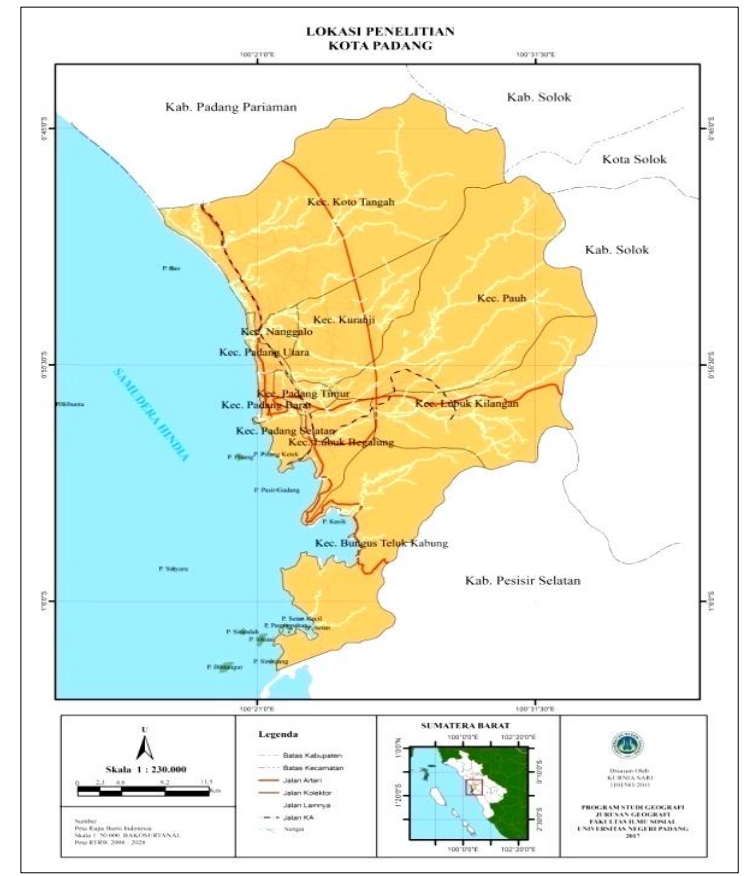

Gambar 1. Lokasi Penelitian Kota Padang

Sampel pada penelitian ini adalah daerah yang mengalami perubahan luas lahan pada tiap kelas kerapatan vegetasi di Kota Padang. Penentuan sampel penelitian ini menggunakan teknik Purposive Sampling, digunakan untuk melakukan pengecekan kebenaran persebaran kerapatan vegetasi Kota Padang pada citra Landsat dengan persebaran kerapatan vegetasi yang ada di lapangan menggunakan GPS (Global Positioning System).

Tabel 3. Nilai indeks kerapatan vegetasi NDVI

\begin{tabular}{cll}
\hline Nilai Indeks Vegetasi NDVI & Klasifikasi Tingkat Kerapatan & \multicolumn{1}{c}{ Nilai Pantul } \\
\hline NDVI 2005 & Tidak Bervegetasi & $-1 \mathrm{~s} / \mathrm{d} 0.25$ \\
$-0.5555 \mathrm{~s} / \mathrm{d} 0.7668$ & Jarang & $0.25 \mathrm{~s} / \mathrm{d} 0.35$ \\
& Cukup Rapat & $0.35 \mathrm{~s} / \mathrm{d} 0.45$ \\
& Rapat & $0.45 \mathrm{~s} / \mathrm{d} 50$ \\
& Sangat Rapat & $0.50 \mathrm{~s} / \mathrm{d} 1$ \\
NDVI 2015 & Tidak Bervegetasi & $-1 \mathrm{~s} / \mathrm{d} 0.25$ \\
$-0.1561 \mathrm{~s} / \mathrm{d} 0.6016$ & Jarang & $0.25 \mathrm{~s} / \mathrm{d} 0.35$ \\
& Cukup Rapat & $0.35 \mathrm{~s} / \mathrm{d} 0.45$ \\
& Rapat & $0.45 \mathrm{~s} / \mathrm{d} 50$ \\
& Sangat Rapat & $0.50 \mathrm{~s} / \mathrm{d} 1$ \\
\hline
\end{tabular}

Sumber: Hasil Analisis Transformasi NDVI

Dari tabel 3. hasil analisis transformasi citra, nilai NDVI dikelompokkan berdasarkan tingkat
Adapun teknik analisis data yaitu analisis kerapatan vegetasi menggunakan $N D V I$, analisis overlay atau tumpang susun peta untuk mengetahui perubahan kerapatan vegetasi, dan uji ketelitian klasifikasi, yaitu cek lapangan pada titik-titik yang dipilih, mencocokan antara data landsat dan petapeta referensi, analisis statistik, dan perhitungan confusion matrix.

\section{HASIL DAN PEMBAHASAN}

HASIL

1. Tingkat Kerapatan Vegetasi Kota Padang

Analisis dilakukan dengan teknik transformasi citra NDVI dengan memanfaatkan band merah, inframerah sebagai band utama dan pemanfaatan band biru dalam analisis. Band merah atau saluran merah dan inframerah pada transformasi NDVI tahun 2005 dan 2015 dengan hasil nilai tunggal citra NDVI berkisar dari $-0,5555 \mathrm{~s} / \mathrm{d} 0,7668$ pada tahun 2005 dan $-0,1561$ s/d 0,6016 pada tahun 2015, ini menunjukkan perbedaan kecerahan vegetasi. Dengan menggunakan teknik density slicing nilai kecerahan NDVI dikelompokan sebagai berikut, lihat pada tabel 3. 
luasan tertinggi pada kedua tahun perekaman, meski demikian luasan dari kerapatan vegetasi kategori sangat rapat juga terus mengalami penurunan, ini terlihat dari luasan-luasan kerapatan vegetasi yang terus berubah.

Hasil analisis transformasi NDVI akan diolah ke perangkat lunak Arcgis 10.1 untuk melihat kerapatan vegetasi tahun
2005 menggunakan Landsat ETM 5 dan tahun 2015 menggunakan Landsat 8.

2. Perubahan Luasan Kerapatan Vegetasi Transformasi NDVI

Berdasarkan hasil analisis citra Landsat 5 tahun 2005 dan Landsat 8 tahun 2015 untuk wilayah Kota Padang dengan menggunakan metode perbandingan nilai NDVI yang disajikan dalam Tabel 4.

Tabel 4. Luas Kerapatan Vegetasi Kota Padang Tahun 2005 dan 2015

\begin{tabular}{cccccccc}
\hline \multirow{2}{*}{ No } & Kerapatan Vegetasi & \multicolumn{2}{c}{$\mathbf{2 0 0 5}$} & \multicolumn{2}{c}{$\mathbf{2 0 1 5}$} & \multicolumn{2}{c}{ Perubahan } \\
\cline { 3 - 7 } & & Luas (Ha) & \% & Luas (Ha) & \% & Luas (Ha) & \% \\
\hline 1 & Tidak Bervegetasi & $12.578,91$ & 17,65 & $14.418,69$ & 20,23 & $1.839,77$ & 2,58 \\
2 & Jarang & $5.124,32$ & 7,19 & $11.424,15$ & 16,03 & $6.299,83$ & 8,84 \\
3 & Cukup Rapat & $5.930,43$ & 8,32 & $27.066,92$ & 37,97 & $21.136,49$ & 29,65 \\
4 & Rapat & $3.382,80$ & 4,75 & $13.960,69$ & 19,59 & $10.577,89$ & 14,84 \\
5 & Sangat Rapat & $44.265,59$ & 62,10 & $4.411,62$ & 6,19 & $-39.853,98$ & $-55,91$ \\
\cline { 2 - 7 } & Jumlah & $\mathbf{7 1 . 2 8 2 , 0 5}$ & $\mathbf{1 0 0 , 0 0}$ & $\mathbf{7 1 . 2 8 2 , 0 5}$ & $\mathbf{1 0 0 , 0 0}$ & &
\end{tabular}

Sumber: Hasil pengolahan nilai NDVI

Berdasarkan hasil analisis citra Landsat 5 tahun 2005 dan Landsat 8 tahun 2015 untuk wilayah Kota Padang. Dilihat dari hasil analisis transformasi NDVI citra Landsat 5 dan Landsat 8 telah terjadi perubahan kerapatan vegetasi seperti kelas sangat rapat yang mengalami penurunan sebesar 55,91\% atau berkurang sebesar 39.853,98 ha dari tahun 2005. Peningkatan dominan terjadi pada kelas vegetasi cukup rapat yang mengalami peningkatan luas sebesar 29,65\% atau 21.136,49 ha peningkatan luas kedua yaitu kelas rapat sebesar $14,84 \%$ atau $10.577,89$ ha diikuti dengan peningkatan kelas jarang sebesar $8,84 \%$ atau $6.299,83$ ha dan kelas tidak bervegetasi sebesar 2,58\% atau 1.839,77 ha.

Berdasarkan perubahan kerapatan vegetasi pada tahun 2005 dan tahun 2015 di kota Padang, terdiri dari sebelas kecamatan pada wilayah penelitian ini. Dari hasil analisis ini tidak semua kecamatan yang mengalami perubahan kerapatan vegetasi yang cukup signifikan, tapi ada beberapa kecamatan yang menjadi orientasi terjadinya perubahan kerapatan vegetasi.
Untuk lebih mudah memahami perubahan kerapatan vegetasi disetiap kecamatan, dijelaskan peta perubahan kerapatan vegetasi transformasi NDVI, untuk lebih jelasnya dapat dilihat pada gambar 5 .

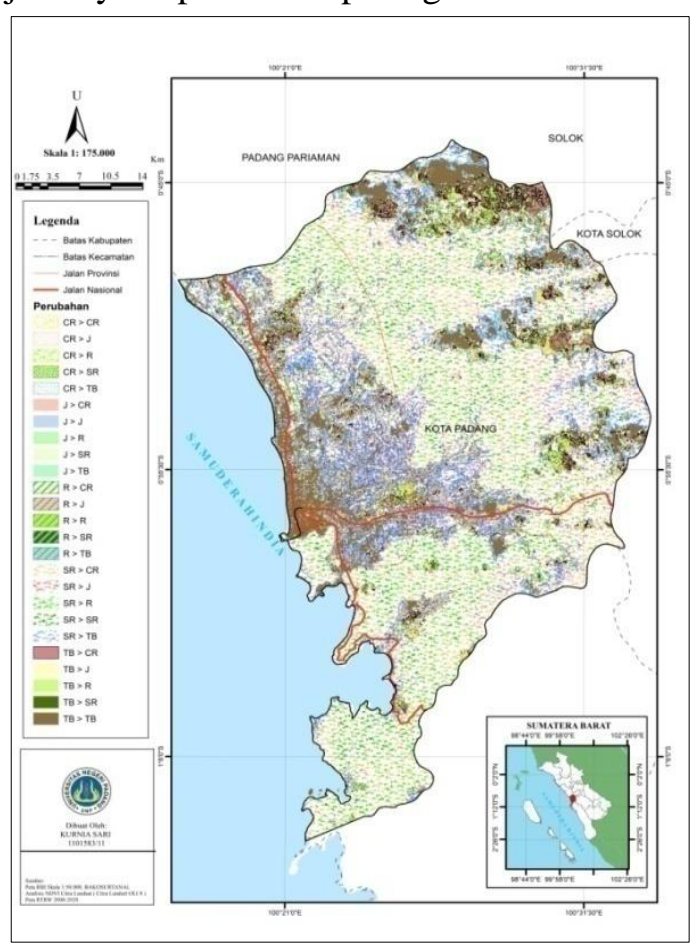

Gambar 5. Peta Perubahan Luas Kerapatan Vegetasi Transformasi NDVI Kota Padang. 
3. Tingkat Ketelitian Citra Menggunakan Uji Akurasi (Confusion Matrix)

a. Penentuan Jumlah Sampel

Proses uji akurasi citra dilakukan dengan teknik confusion matrix. Proses ini dilakukan pengambilan sampel lapangan dengan ukuran sampel ploting area, penentuan lokasi dilakukan dengan pemilihan lokasi yang mampu mewakili secara purposif sampling sesuai saran (Mc Coy, 2005 dalam Hanif, 2015). Teknik ini dipilih karena melihat kondisi fisik atau lokasi penelitian yang tidak semuanya dapat ditempuh dengan mudah, beberapa lokasi memiliki kondisi morfologis yang tidak mudah untuk ditempuh. Jumlah sampel dalam penelitian ini dijabarkan sebagai berikut:

$$
\begin{aligned}
& N=Z^{2}(p)(q) / E^{2} \\
& \begin{aligned}
\mathrm{N} & =(2)^{2} \times 85 \times(100-85) /(5)^{2} \\
& =340 \times(15) / 25 \\
& =340 \times 0,6 \\
& =204 \text { sampel }
\end{aligned}
\end{aligned}
$$

Akurasi $85 \%$ yang diharapkan, dengan kesalahan yang diijinkan dari (tingkat kepercayaan 95\%), 204 sampel akan dibutuhkan dalam menggunakan pendekatan ini. Hasil data perolehan lapangan dibandingkan dengan hasil Tabel 5. Uji Akurasi (Confusion Matrix) intrepetasi citra, titik sampel citra sudah ditentukan sebanyak 204 sampel (Febriandi,2017).

b. Penentuan Ukuran Sampel

Penentuan ukuran sampel ploting area ini untuk dilakukan uji akurasi citra dengan metode confusion matrik. Ukuran sampel ditentukan sebagai berikut ini:

$$
\mathrm{A}=\mathrm{P}(1+2 \mathrm{~L})
$$

Dalam penelitian ini citra yang digunakan adalah citra landsat TM5 dan OLI8 memiliki resolusi 30-m pixel, dan (Mc. Coy, 2005) menyarankan untuk akurasi lokasi dari setiap piksel untuk citra landsat akurasi lokasionalnya 0,5. Maka, ukuran sampel ploting area untuk dilakukanya sebagai berikut:

$\mathrm{A}=30 \mathrm{~m}(1+(2.0,5))$

$=30(2)$

$=60 \mathrm{~m} \times 60$

Sampel yang harus diambil disetiap kategori klasifikasi kerapatan vegetasi adalah $60 \mathrm{~m}$ x $60 \mathrm{~m}$. Selain dilakukan pengambilan sampel ploting area, juga

\begin{tabular}{|c|c|c|c|c|c|c|c|}
\hline & & \multicolumn{5}{|c|}{ Data Acuan (diambil dari data independen) } & \multirow[b]{2}{*}{$\begin{array}{l}\text { Tota } \\
\text { Bari }\end{array}$} \\
\hline & & $\begin{array}{c}\text { Tidak } \\
\text { Bervegetasi } \\
\text { (Air, Laut, } \\
\text { Tambak, dan } \\
\text { Waduk) }\end{array}$ & $\begin{array}{c}\text { Jarang (Lahan } \\
\text { Permukiman, } \\
\text { Tanah Terbuka, } \\
\text { Bangunan) }\end{array}$ & $\begin{array}{c}\text { Cukup } \\
\text { Rapat } \\
\text { (Tegalan, } \\
\text { Sawah, } \\
\text { Padang } \\
\text { Rmput) } \\
\end{array}$ & $\begin{array}{c}\text { Rapat } \\
\text { (Perkebunan, } \\
\text { Semak Belukar) }\end{array}$ & $\begin{array}{c}\text { Sangat } \\
\text { Rapat } \\
\text { (Hutan } \\
\text { Lebat) }\end{array}$ & \\
\hline \multirow{5}{*}{$\begin{array}{l}\text { Hasil } \\
\text { Klasifik } \\
\text { asi }\end{array}$} & $\begin{array}{l}\text { Tidak Bervegetasi (Air, Laut, } \\
\text { Tambak, dan Waduk) }\end{array}$ & 49 & 2 & 1 & 0 & 0 & 52 \\
\hline & $\begin{array}{l}\text { Cukup Rapat (Tegalan, } \\
\text { Sawah, Padang Rmput) }\end{array}$ & 2 & 1 & 55 & 1 & 1 & 60 \\
\hline & $\begin{array}{l}\text { Rapat (Perkebunan, Semak } \\
\text { Belukar) }\end{array}$ & 0 & 0 & 0 & 24 & 2 & 26 \\
\hline & Sangat Rapat (Hutan Lebat) & 0 & 0 & 1 & 1 & 17 & 19 \\
\hline & Total Kolom & 53 & 46 & 58 & 27 & 20 & 204 \\
\hline
\end{tabular}
dapat dibantu dengan pengambilan sampel training area metode (ROI) dengan perangkat ENVI sesuai yang disarankan oleh (Danoedoro, 2012).

c. Akurasi NDVI (Confusion Matrix)

Sumber: Survei dan analisis citra agustus 2018 
Hasil akurasi ketelitian citra:

$$
\begin{aligned}
\text { MA }= & (\text { Xcr pixel }) /(\text { Xcr pixel }+ \text { Xo pixel } \\
& + \text { Xco pixel }) * 100 \% \\
= & 188 /(188+16+16) * 100 \% \\
= & 188 / 220 * 100 \% \\
= & 85,45 \% \\
& \text { Dilihat dari tabel } 5 \text { hasil uji akurasi }
\end{aligned}
$$
NDVI, diperoleh akurasi $85,45 \%$, dari uji akurasi ini diperoleh kesalahan untuk tingkat kerapatan vegetasi tidak bervegetasi sebanyak empat sampel, dua sampel masuk ke dalam kelas jarang, satu sampel masuk ke dalam kelas cukup rapat, satu sampel masuk ke dalam kelas rapat. Kesalahan juga terdapat pada tingkat kerapatan vegetasi jarang sebanyak lima sampel, dua sampel masuk ke dalam kelas tidak bervegetasi, satu sampel masuk ke dalam kelas cukup rapat, satu sampel masuk ke dalam kelas rapat, dan satu sampel masuk ke dalam kelas sangat rapat.

Kesalahan analisis juga ditemukan pada kategori cukup rapat, ditemukan dengan masuknya lima sampel ke dalam kelas lain berupa, dua sampel masuk kedalam kategori kerapatan vegetasi tidak bervegetasi, satu sampel masuk kedalam kategori kerapatan vegetasi jarang, satu sampel masuk ke dalam kelas kerapatan vegetasi rapat, dan satu sampel masuk ke dalam kelas kerapatan vegetasi sangat rapat.

Pada kesalahan selanjutnya juga ditemukan pada kategori rapat sebanyak 2 sampel masuk ke dalam kelas kerapatan vegetasi sangat rapat. Ketidak tepatnya analisis juga terlihat dari masuknya kategori sangat rapat ke dalam kelas lain, satu sampel masuk kedalam kategori cukup rapat dan satu sampel masuk ke dalam kelas rapat.

\section{PEMBAHASAN}

Pertama Tingkat kerapatan vegetasi dalam penelitian ini dikategorikan kepada lima kelas kerapatan, dengan perolehan hasil tingkat kerapatan vegetasi kerapatan tinggi merupakan tingkatan yang memiliki luasan area yang besar setiap tahunnya. Vegetasi dengan tingkat kerapatan tinggi yang ditemukan di lapangan berupa hutan dengan vegetasi yang rapat dan berdaun hijau lebat, pada kategori kerapatan vegetasi jarang dilakukan survey lapangan dengan perolehan data lapangan berupa kumpulan vegetasi penyusun kebun campuran dan beberapa kategori lain. Pada kategori kerapatan jarang ditemukan objek dengan sedikit komposisi vegetasi.

Tingkat kerapatan vegetasi yang telah dijelaskan menujukkan adanya variasi komposisi vegetasi di lapangan yang memberikan respon berbeda pada saluran inframerah dekat dan saluran merah pada data hasil perekaman citra. Pada objek dengan komposisi vegetasi kerapatan tinggi memberikan nilai kecerahan vegetasi yang tinggi pula, saat komposisi vegetasi menurun kerapatan vegetasi juga menurun. Semakin rapat komposisi vegetasi yang menutupi suatu lahan maka tingkat kerapatan vegetasi akan terdeteksi menjadi kerapatan yang lebih tinggi, dengan pantulan gelombang inframerah dekat dan gelombang merah yang direspon oleh vegetasi. Hasil penelitian ini sesuai dengan pendapat (Sudiana, 2008) dengan simpulan nilai kehijauan vegetasi diperoleh dari nilai kecerahan vegetasi, karena adanya proses pantulan dari klorofil oleh vegetasi. Hasil penelitian ini menunjukkan pada tingkat kerapatan tinggi merupakan hutan lebat yang memiliki daun hijau dan lebat dengan tingginya kandungan klorofil.

Kedua perubahan kerapatan luas lahan bervegetasi, dari hasil analisis citra menggunakan transformasi citra NDVI yang kemudian dilakukan overlay peta untuk mengetahui perubahan kerapatan vegetasi, diperoleh hasil yang berbeda pada periode perhitungan. Perubahan kerapatan luas lahan bervegetasi dari tahun $2005 \mathrm{ke}$ tahun 2015. Perubahan beupa penambahan 
luasan vegetasi dan penurunan kerapatan vegetasi. Dilihat dari peta tutupan lahan tahun 2005 dapat ditarik kesimpulan, penurunan kerapatan vegetasi pada kategori kerapatan sangat rapat dan penambahan luas pada kategori kerapatan rapat, cukup rapat, jarang, dan tidak bervegetasi.Hal ini dipengaruhi oleh faktor tutupan lahan (land cover), keadaan tutupan lahan tahun 2005 mempengaruhi kerapatan vegetasi penutup lahan.

Dari hasil analisis citra penambahan luasan kerapatan vegetasi lebih sedikit daripada pengurangan luasan kerapatan vegetasi, penurunan luasan kerapatan vegetasi lebih banyak terjadi dan terfokus di Kecamatan Koto Tangah. Kondisi tutupan lahan pada wilayah perubahan ini diinterpretasi pada peta tutupan lahan tahun 2015 berupa lahan terbangun, sawah, kebun campuran/belukar dan hutan. Penyebab perubahan kerapatan vegetasi salah satu faktor berupa aktifitas manusia dalam pengelolaan lahan. Kegiatan manusia dalam pengolahan lahan mempengaruhi land cover dan kerapatan vegetasi. Faktor aktivitas manusia menjadi faktor yang cukup berpengaruh dikarenakan kerapatan vegetasi cukup rapat dan jarang merupakan kebun campuran, area pertanian. Kebun campuran dan area pertanian merupakan aktiftas penggunaan lahan yang dikelola oleh manusia. Hasil analisis perubahan kerapatan vegetasi yang juga didampingi dengan diinterpretasi peta tutupan lahan, perubahan kerapatan vegetasi ini sesuai dengan pernyataan (Sitanala, 2012 dalam Hanif, 2015) dengan kesimpulan bahwasanya perubahan penggunaan lahan merupakan bentuk konektifitas logis dari pertumbuhan transfromasi struktur sosial,ekonomi masyarakat.

Hasil analisis dan cek lapangan pengurangan luasan terbesar terjadi pada kelas kerapatan vegetasi sangat rapat tahun 2005-2015. Dengan perubahan luas dari
44.265,59 Ha tahun 2005 berkurang menjadi 4.411,62 Ha pada tahun 2015.

Ketiga hasil analisis citra multi temporal dari transformasi citra NDVI transformasi vegetasi diperoleh nilai minimum dan maksimum yang berbedabeda dari setiap periode perekaman citra.

Tabel 6. Nilai minimum dan maksimum

\begin{tabular}{cccc}
\hline \multirow{2}{*}{ No } & \multirow{2}{*}{ Tahun } & \multicolumn{2}{c}{ NDVI } \\
\cline { 3 - 4 } & & Minimum & Maksimum \\
\hline 1 & 2005 & $-0,5555$ & 0,7668 \\
\hline 2 & 2015 & $-0,1561$ & 0,6016 \\
\hline
\end{tabular}

Sumber : hasil citra landsat pengolahan NDVI

Dari tabel variasi nilai minimum dan maksimum hasil perekaman citra ini disebabkan oleh beberapa fakor, (1) efek atmosfer, berupa (tutupan awan, hamburan cahaya dan penyerapan gelombang) hal ini dapat dilihat pada citra warna nyata setiap tahun perekaman citra yang digunakan dalam penelitian ini, (2) sudut datang cahaya, yang mana citra satelit didalam penelitian ini digunakan citra satelit Landsat TM5 dan OLI8, yang mana satelit Landsat TM5 pukul 10.00 WIB dan OLI8 melakukan perekaman sekitar pukul 10.11 WIB, waktu ini merupakan saat terjadinya evaporasi yang cukup besar sehingga banyaknya bermunculan butiran awan di atmosfer yang mempengaruhi nilai pantulan cahaya yang merambat ke bumi dan pantulan cahaya yang direkam oleh sensor, gangguan atmosfer berupa awan ini dapat dilihat pada citra warna nyata yang digunakan dalam penelitian ini. Posisi matahari sebagai sumber cahaya, objek dan sensor membentuk sudut pantulan bidireksional sehingga, gangguan atmosfer diwilayah lain akan mempengaruhi kualitas citra yang direkam oleh sensor. Maka dari itu meskipun kondisi vegetasi di lapangan rapat dengan kandungan klorofil tinggi nilai pantul klorofil tanaman akan terganggu oleh kondisi atmosfer. 
Hasil cek lapangan memberikan informasi bahwa perubahan kerapatan vegetasi yang terjadi ini didukung karena adanya perubahan penggunaan lahan hutan homogen dan semak belukar menjadi penggunaan lahan sawah, tegalan, perkebunan, daerah terbangun ataupun lahan kosong belum ada pemanfaatan. Pemanfaatan penggunaan lahan sebagai area terbangun dilakukan untuk memenuhi kebutuhan penduduk Kota Padang yang semakin tahun meningkat pada tiap tahunnya.

\section{PENUTUP}

Kesimpulan

Berdasarkan hasil penelitian tentang analisis perubahan kerapatan vegetasi dengan menggunakan citra penginderaan jauh berupa citra Landsat tahun perekaman 2005 dan 2015 serta survei lapangan di Kota Padang, maka dapat diuraikan beberapa kesimpulan sebagai berikut:

1. Terjadi perubahan kerapatan vegetasi di Kota Padang selama kurun waktu 2005 hingga 2015. Perubahan terbesar terjadi pada tingkat kerapatan vegetasi sangat rapat yang dipresentasikan dengan bentuk tutupan lahan hutan tropis dengan dedaunan yang sangat rapat, tingkat kerapatan vegetasi sangat rapat ini mengalami penurunan sebesar $55,91 \%$ dari luas semula. Namun peningkatan kerapatan terjadi pada empat kelas kerapatan vegetasi lainnya yaitu tidak bervegetasi (air, laut, tambak, waduk, lahan kosong) sebesar 2,58\%, jarang (lahan terbangun/permukiman, ) sebesar $8,84 \%$, cukup rapat (pertanian lahan basah, pertanian lahan kering) sebesar $29,65 \%$, dan kelas kerapatan rapat (semak belukar, perkebunan) sebesar $14,84 \%$.

2. Dari hasil analisis dan cek lapangan pengurangan luasan terbesar terjadi pada kelas kerapatan vegetasi sangat rapat tahun 2005-2015. Dengan perubahan luas dari 44.265,59 Ha tahun 2005 berkurang menjadi 4.411,62 Ha pada tahun 2015. Dari hasil analisis citra kerapatan vegetasi ini telah terjadi pengurangan informasi yang disebabkan adanya tutupan awan dan kerusakan citra pada tahun 2015 yang dinamakan (SLC-Off). Perubahan tingkat kerapatan vegetasi di Kota Padang disebabkan oleh perubahan dan perkembangan tutupan lahan, dimana lahan perkebunan menjadi lahan-lahan terbangun seperti pemukiman, perkantoran serta pusat-pusat perbelanjaan/bisnis.

3. Tingkat ketelitian citra Landsat dari hasil uji akurasi NDVI dengan teknik pengolahan Confussion Matrix, diperoleh akurasi $85,45 \%$, telah terjadi pengurangan informasi yang disebabkan adanya tutupan awan dan kerusakan citra pada tahun.

\section{Saran}

1. Diharapkan dalam penelitian selanjutnya mengenai kerapatan vegetasi di Kota Padang menggunakan data citra penginderaan jauh yang mempunyai resolusi tinggi, tidak mengalami $S L C$-Off, dan tidak adanya gangguan awan. Sehingga diperoleh data yang lebih akurat dan lebih baik untuk digunakan sebagai bahan pertimbangan dalam melakukan perencanaan tata ruang kota.

2. Diharapkan kepada pemerintah dan masyarakat melakukan memanfaatkan pekarangan rumah dengan ditanami vegetasi, dan melestarikan vegetasi. Sehingga keberadaan vegetasi tetap memberikan konstribusi dalam menciptakan suasana fungsional, efisien, nyaman, sehat, dan estetis. 
DAFTAR PUSTAKA

Anargi, Septiyaji B. 2008. Aplikasi Sistem Informasi Geografis Untuk Pemetaan Perubahan Penggunaan Lahan Kota Semarang Tahun 1994 Dan Tahun 2005. Skripsi. Universitas Negeri Semarang.

Badan Pusat Statistik. 2016. Kota Padang Dalam Angka. Padang: Badan Pusat Statistik Kota Padang.

Virma, Careca. 2013. Analisis Perubahan Kerapatan Vegetasi Kota Semarang Menggunakan Bantuan Teknologi Penginderaan Jauh. Skripsi. Universitas Negeri Padang.

Projo, Danoedoro. 2012. Pengantar Penginderaan Jauh Digital. Yogyakarta: Andi Offset.

Febriandi. 2017. The Estimation Of Mangroves Area and Density of Mangroves Changes Use the Remote Sensing Data at Northheast Province of Aceh, Indonesia.
Sumatra Journal of Disaster, Geography and Geography Education. Vol.1. No.1 (105-110), June 2017 ISSN 2580-4030. Universitas Negeri Padang.

Rahmi, Julia. 2009. Hubungan Rerapatan Tajuk dan Penggunaan Lahan Berdasarkan Analisis Citra Satelit dan Sistem Informasi Geografis di Taman Nasional Gunung Leuser. Skripsi.Universitas Sumatera Utara.

Hanif, Muhammad. 2016. Studi Perubahan Kerapatan Vegetasi Catchment Area Danau Maninjau Dengan Teknologi Penginderaan Jauh dan Sistem Informasi Geografi. Skripsi. Universitas Negeri Padang.

Dodi, Sudiana. 2008. Analisis Indeks Vegetasi menggunakan Data Satelit NOAA/AVHRR dan TERRA/AQUAMODIS. Jurnal. Faultas Teknik. Universitas Indonesia. Depok. ISBN 978-979-8897-24-5. 